\title{
Instrumentation and implementation of pain evaluation scale in a Neonatal Intensive Care Unit. Case report*
}

\author{
Instrumentalização e implantação de escala para avaliação da dor em Unidade de Terapia \\ Intensiva Neonatal. Relato de caso
}

Cibele Thomé da Cruz¹, Eniva Miladi Fernandes Stumm²

${ }^{*}$ Received from Regional University of the Northwestern State of Rio Grande do Sul, Ijuí, RS, Brazil.

DOI 10.5935/1806-0013.20150046

\section{ABSTRACT}

BACKGROUND AND OBJECTIVES: Premature neonates admitted to Neonatal Intensive Care Units receive approximately 130 to 234 manipulations every $24 \mathrm{~h}$, being many of them painful approaches. So, nursing team education and instrumentation are important for pain evaluation with a validated scale, which is excellence and safety assurance for patients' care. In light of the above, our objective was to describe how instrumentation of the nursing team of a Neonatal Intensive Care Unit was carried out to implement the Neonatal Infant Pain Scale for neonatal pain evaluation.

CASE REPORT: After literature review and definition of the Neonatal Infant Pain Scale for pain evaluation, the nursing team acting in that unit was instrumented for its application together with other vital signs. In addition, a pain handling protocol was developed. During instrumentation, opportunity was given for questions and answers. Of note is the importance of nurses' contributions aiming at making feasible the implementation of this scale and of the pain handling protocol.

CONCLUSION: It was observed that as from the moment the team has enhanced its knowledge about neonatal pain, many questions were asked about actions to be taken by the team with regard to the evaluated pain. In this sense, it is considered that nurses should play their role as health education protagonists, thus assuring quality of care. It has also to be stressed the importance of study groups focusing on pain evaluation in intensive care and other hospital units.

Keywords: Neonatal Intensive Care Unit, Neonate, Nursing, Pain measurement, Premature.

1. Associaçấo Hospital de Caridade de Ijuí. Unidade de Terapia Intensiva Neonatal, Ijui, RS, Brasil. 2. Universidade Regional do Noroeste do Estado do Rio Grande do Sul, Departamento de Ciências da Vida, Ijui, Brasil.

Submitted in March 21, 2015

Accepted for publication in July 29, 2015.

Conflict of interests: none - Sponsoring sources: none.

Correspondence to:

Cibele Thomé da Cruz

Rua Ceará, 615 - Bairro Glória

98700-000 Ijuí, RS, Brasil.

E-mail: cibelethome@bol.com.br

(C) Sociedade Brasileira para o Estudo da Dor

\section{RESUMO}

JUSTIFICATIVA E OBJETIVOS: O recém-nascido prematuro em Unidade de Terapia Intensiva Neonatal recebe cerca de 130 a 234 manipulações em $24 \mathrm{~h}$, muitas delas dolorosas. Assim, é importante a educação e instrumentalização da equipe de enfermagem, para que ocorra a avaliação da dor com a utilização de escala validada, que é garantia de excelência e segurança no cuidado ao paciente. Diante disso, objetivou-se descrever como ocorreu a instrumentalização da equipe de enfermagem de uma Unidade de Terapia Intensiva Neonatal para implantação da escala Neonatal InfantPainScale para avaliação da dor de recém-nascidos.

RELATO DO CASO: Após revisão de literatura e definição da escala Neonatal InfantPainScale para avaliação da dor foi realizada instrumentalização da equipe de enfermagem que atua na unidade, para sua aplicação com os demais sinais vitais. Além disso, foi criado um protocolo de manuseio da dor. Durante a instrumentalizaçáo foi dada oportunidade para questionamentos e respostas às dúvidas. Ressalta-se a importância das contribuiçốes do enfermeiro com vistas a viabilizar a implantação dessa escala e do protocolo do manuseio da dor.

CONCLUSÃO: Evidenciou-se que a partir do momento em que a equipe ampliou conhecimentos sobre a dor do recém-nascido, emergiram vários questionamentos a respeito de açôes a serem realizadas pela equipe diante da dor avaliada. Nesse aspecto considera-se que o enfermeiro deve assumir seu papel de protagonista na educação em saúde e, dessa maneira, garantir a qualidade da assistência. Ainda, destaca-se a importância da formaçáo de grupos de estudo com enfoque na avaliação de dor em terapia intensiva e demais unidades hospitalares.

Descritores: Enfermagem, Prematuro, Mensuração da dor, Recém-nascido, Unidade de Terapia Intensiva Neonatal.

\section{INTRODUCTION}

Pain is a common phenomenon among human beings, be them adults, children, infants or newborns (NB). However, pain is manifested in different ways, which may impair the evaluation and/or interpretation of pain indicators. Pre-verbal infants, especially NBs, do not verbalize pain, but this does not mean that they do not feel it; they manifest pain through behavioral and physiological responses to nociceptive stimulations. 
Within this concept and to adequately act in face of potential painful situations, in addition to knowing that NBs express pain, it is important to have tools to "decode" this language. Even with major advances, the literature still has a gap between scientific knowledge of the subject and its consequences and the use of methods to evaluate and manage pain ${ }^{1}$.

Pain stimulation and perception are present before birth. Nervous terminations appear in the perioral region in the seventh week of gestation and proceed to palms and plantar region in the $11^{\text {th }}$ week, to the body and proximal extremities in the $15^{\text {th }}$ week and, approximately in the $20^{\text {th }}$ to $24^{\text {th }}$ week nervous synapses are ready for pain perception ${ }^{2}$.

During NB admission to a Neonatal Intensive Care Unit (NICU), pain is a frequent symptom, related to severe clinical presentations and to several invasive procedures. Premature NBs (PNB) are submitted to approximately 130 to 234 manipulations per day in the NICU, some of them painful ${ }^{3}$. It is believed that this situation could be lived by NBs in a less traumatic way if professionals in charge of their care were sensitized to the importance of adequate pain evaluation and measurement.

Based on these considerations, pain management in the NICU should be priority of the therapeutic program for critical and potentially critical NBs, because its adequate management brings numerous benefits for the child, in addition to decreasing hospitalization time and consequently $\operatorname{costs}^{4}$. On the other hand, repeated painful exposures may have severe consequences. Italian investigators state that $\mathrm{NBs}$ with higher risk of neuro-development disorders as result of prematurity are also those with probability of being exposed to a larger number of painful stimulations in the NICU ${ }^{5}$.

In general, inadequate pain control is related to the lack of evaluation and recording criteria and methods. Although evaluating and measuring pain are complex tasks, these procedures should integrate the routine of the nursing team, with records of such information in children's medical charts, followed by pain relief actions. Most health professionals consider pain as the fifth vital sign to be evaluated and know specific scales for PNB pain evaluation, but in general they do not use them as routine. In this sense, education and instrumentation of the nursing team are critical for pain evaluation with validated scales, so as to assure patient's care excellence and safety.

A study aiming at knowing the experience of 109 intensivist nurses taking care of children and newborns with regard to evaluation and interventions for pain relief, has shown that pain relief and comfort promotion are essential interventions which involve, in addition to scientific knowledge and technical skills, nursing humanitarian and ethic issues ${ }^{6}$. So, evaluating pain is a challenge implying scientific knowledge allied to adequate records and actions, not necessarily pharmacological measures, aiming at relieving pain ${ }^{7}$.

In light of the above, this study aimed at describing how the nursing team was instrumented to implement a pain evaluation scale in NICU.

\section{CASE REPORT}

Nursing actions in a Pediatric NICU (NICUP) allied to academic history have led to several questions and also to rethinking the possibility of better evaluating $\mathrm{NB}$ pain in the intensive care unit. These concerns have led to the development of the research project of the Graduation Course Conclusion Study about pain evaluation in NBs admitted to NICU.

This report contemplates the stages of instrumentation of the nursing team for the implementation of a pain evaluation scale in the NICU. Initially, a meeting with the Chief-Nurse of the Unit was scheduled and she was receptive to the idea.

Following, the research project was developed and all ethical aspects of a research with people were respected. We tried to enhance knowledge about the subject, the implications triggered by pain on NBs, increased mortality, stress, clinical and hemodynamic instability, neurological development sequelae and abnormal somatization of pain in other stages of life, which may be considered negative consequences of repeated painful stimulations in the neonatal period ${ }^{8}$. This way, decreased exposure to painful or stressing events may lead to better clinical results associated to NB neurological development.

The NICUP where instrumentation and implementation of pain evaluation scale were carried out has nine neonatal beds and one pediatric bed. Workforce is made up of five nurses, 28 nursing technicians, 10 pediatricians, 4 physiotherapists and one speech therapist.

Based on literature review, we decided to use the Neonatal Infant Pain Scale (NIPS) to evaluate pain, especially for being a validated tool, for contemplating physiological and behavioral aspect of NB with pain, for being easily applied and for meeting our proposed objectives. Nursing team instrumentation was performed in four different moments. The first was in a hospital meeting room, and has lasted one hour with the presence of the whole nursing team in a total of 33 professionals. This meeting has contemplated theoretical knowledge about pain, physiology, research results, and using pain evaluation scales with emphasis on NIPS. Many questions were raised during this meeting, which were gradually answered. The three next meetings were carried out in the ICU itself, and were previously scheduled with nurses of respective shifts. In these meetings, the pilot stage was started and consisted in the application of the NIPS scale to the six NBs admitted in the morning, afternoon and evening shifts, with follow-up of all present nursing professionals. After the analysis, the adequacy of the tool was confirmed and it was identified that the team was in conditions, that is, was qualified to apply the NIPS scale every $2 \mathrm{~h}$, together with other newborn vital signs. During scale application practice, nursing professionals reported many times to the need of implementing measures to be taken face to NB pain. This position was determinant to give continuity to the research, moment in which nurses were sensitized together with investigators for the development and implementation of a pain handling protocol, including non-pharmacological measures for its relief. 
There have been important advances in recent years with regard to pain evaluation with the validation of objective criteria which may be used in different places. Pain standardization as the fifth vital sign by the Joint Commission on Accreditation of Healthcare Organizations (JCAHO) is considered one of such advances for listing as priorities the evaluation (location and intensity) based on behavioral scales and physiological parameters, the intervention and revaluation of pain in the process of hospital qualification ${ }^{3}$.

NBs are unable to inform pain site and its intensity, so it is up to the nursing team to evaluate NBs, because they are the ones providing direct continuous care to newborns, in the sense of contributing to the planning of fast and adequate actions, aiming at considering the individuality and uniqueness of each patient ${ }^{9}$. It should be stressed that we have tried to value issues regarding nursing care, to be alert to newborn physiological and behavioral parameters and that when evaluating pain as a vital sign, the team qualifies and personalizes assistance.

\section{CONCLUSION}

The experience has led to the implementation of pain evaluation as the fifth vital sign in the NICU, followed by its follow-up. As from the moment the team has enhanced their knowledge about NB pain and about its implications, they were mobilized and took the activity to them. There is the need to developing quality indicators to evaluate the effectiveness of the pain evaluation scale implementation for NB admitted to that unit.
As from this experience, many issues have been raised about actions to be taken by the team in face of the evaluated pain and, in this sense, it is noticed the importance of a team committed to assistance. It is considered that nurses should play their role as health education protagonists and this way assure quality of assistance to newborns.

Our results point to actions which may and should be taken by the nursing team working in NICUs, aiming at evaluating pain and, face to obtained results, at planning and implementing care to manage NB pain. In addition, it should be stressed the importance of study and research groups focusing on instrumentation and implementation of pain evaluation scales in neonatal intensive care units and other hospital units.

\section{REFERENCES}

1. Lago P, Garetti E, Boccuzzo G, Merazzi D, Pirelli A, Pieragostini L, et al. Procedura pain in neonates: the state of the art in the implementation of national guidelines in Italy. Paediatr Anaesth. 2013;23(5):407-14

2. Tamez RN, Silva MJ. Enfermagem na UTI neonatal: assistência ao recém-nascido de alto risco. Rio de Janeiro: Guanabara Koogan; 2010. 69-70p.

3. Santos LM, Pereira MP, dos Santos LF, de Santana RC. [Pain assessment in the premature newborn in Intensive Care Unit]. Rev Bras Enferm. 2012;65(1):27-33. Portuguese.

4. Silva LD, Lima LS, Tacla MT, Ferrari RA. Scales of assessment of pain: the process of implementation in a pediatric intensive care unit. Rev Enferm UFPE. 2014;8(4):857-63.

5. Giacchetti L, Stablum M, De Martino A, Giustardi A. Pain in newborn. Ital J Pediatr. 2014;40(Suppl 1):A54.

6. dos Santos MZ, Kusahara DM, Pedreira Mda L. [The experiences of intensive care nurses in the assessment and intervention of pain relief in children]. Rev Esc Enferm USP. 2012;46(5):1074-81. Portuguese.

7. Silva MS, Pinto MA, Gomes LM, Barbosa TL. Pain in hospitalized children: nursing team perception. Rev Dor. 2011;12(4):314-20.

8. Maia AC, Coutinho SB. Fatores que influenciam a prática do profissional de saúde no manejo da dor do recém-nascido. Rev Paul Pediatr. 2011;29(2):270-6.

9. Alves VS, Santos TS, Trezza MC, Santos RM, Monteiro FS. Conhecimento de profissionais da enfermagem sobre fatores que agravam e aliviam a dor oncológica. Rev Bras Cancerol. 2011;57(2):199-206. 